\title{
Orthopedic Implant Used as Drug Delivery System: Clinical Situation and State of the Research
}

\author{
Dominique P. Pioletti ${ }^{1}$ * , Olivier Gauthier ${ }^{2}$, Vincent A. Stadelmann ${ }^{1}$, Bruno Bujoli ${ }^{3}$, Jérôme Guicheux ${ }^{2}$, \\ Pierre-Yves Zambelli ${ }^{4}$ and Jean-Michel Bouler ${ }^{2}$
}

\begin{abstract}
${ }^{1}$ Laboratory of Biomechanical Orthopedics EPFL-HOSR, Institute of Translational Biomechanics, Ecole Polytechnique Fédérale Lausanne, Switzerland; ${ }^{2}$ Laboratoire de Recherche sur les Materiaux d'Intérêt Biologique INSERM 99-03, Faculté de Chirurgie Dentaire, Nantes, France; ${ }^{3}$ Laboratoire de Synthèse Organique UMR CNRS 6513, Faculté des Sciences, Nantes, France; ${ }^{4}$ Hopital Orthopédique de la Suisse Romande, Lausanne, Switzerland
\end{abstract}

\begin{abstract}
A partial review is proposed on the existing literature for the research performed in orthopedic implant used as drug delivery system. In the first part, an evaluation is given on the clinical need to deliver a drug in the surrounding of an implant. Secondly, a review of the clinical situation is developed for implants already used as drug delivery system. Experimental works performed for local delivery are reported. In particular, a description is given on the in vitro and in vivo studies where the implant is coated with different proteins or drugs. Finally, a conclusion is proposed on the next step in the development of orthopedic implant as drug delivery system mentioning also the industrial situation.
\end{abstract}

Keywords: Orthopedic implant, local delivery, drug, bone remodelling.

\section{IS THERE A CLINICAL NEED FOR LOCAL DELIVERY OF DRUG AROUND ORTHOPEDIC IMPLANT?}

Orthopedic practice recently enters a new area by considering use of drugs to enhance the fixation of implants. The rational behind this approach is to keep the bone around the implant as the trend observed clinically is a peri-implant bone resorption for hip or knee implants. Studies over the past 2 decades have strongly implicated osteoclasts as the major cause of the bone lysis leading to implant failure [1, 2]. Different activation pathways of osteoclasts have been identified and in particular the RANKL/OPG/RANK pathway has been given much interest [3]. Decreasing the catabolic bone activity would then be a good strategy to avoid peri-implant bone loss. The drug of choice so far is of bisphosphonate type and several clinical trials have been performed and effectively show a reduction of peri-implant bone loss in treated groups [4-6]. Systemic injections of a drug may then be potentially interesting to control the bone remodeling around orthopedic implant, however this mode of delivery may not be optimal.

The failure of an orthopedic implant is strongly correlated to its bone fixation [7]. When an implant is used without cement, stability immediately after the surgery must be obtained, a process called primary fixation, followed by a long-term fixation, a process called secondary fixation. A race on fixation quality is then engaged with the concept that the faster the secondary implant fixation is obtained, the better will be the implant outcome. The primary fixation being insured by the press-fit technique, the drug should then target the secondary fixation with the goal of reducing the bone loss. We should not be mislead by the term secondary fixation which is indeed already happening during the first months following the surgery. This has been shown in a clinical study where up to $14 \%$ bone loss arose during the first three months after total hip arthroplasties [8]. In parallel, rapid early migrations have been detected by roentgen stereophotogrammetry in many asymptotic hips, often as early as four months postoperatively [9]. The migrations have been found to predict an increased risk of clinical loosening.

Systemic delivery of bisphosphonate by several injections over months may then not furnish enough drugs on time in the peri-

*Address correspondence to this author at the EPFL/STI/IBME/LBO, Station 15, 1015 Lausanne, Switzerland; Tel: ++41 2169383 41; Fax: ++41 21 69386 60; E-mail: dominique.pioletti@epfl.ch implant bone to render the therapy effective for a rapid secondary fixation. Indeed, recent clinical studies have shown that systemic bisphosphonate treatment following a prosthesis implantation reduced peri-implant bone loss only 3 months after the treatment [4, 5]. Moreover, proximal femur, the region where most of the bone resorption occurs, is reached with difficulty by bisphosphonate systemically injected as shown by the lower decrease of femur fracture prevention compared to vertebra fracture prevention in a phase III clinical studies for osteoporosis treatment with systemic bisphosphonate treatment [10].

As the targeted skeleton site is limited to the peri-implant bone, the drug access is not easily reached by systemic delivery and the drug should be rapidly available, it will then make sense to use the implant itself as a drug delivery system enabling to overcome the limitations of the systemic delivery. Moreover, by local delivery, the drug amount is decreased, reducing then potential side effect of the drug.

With this idea to associate to the implants a drug in order to enhance the bone fixation or to reduce the bone resorption, the most indicated implants category remains the uncemented. Classically the uncemented hip prosthesis are selected for young patient with an acceptable bone stock. The results of the Australian and Swedish register demonstrate that for young patient, the problems result essentially because of the wear particles liberated in function of the tribological characteristics of the femoral head and the socket [11, 12]. For this category of patients, the initial fixation and furthermore the secondary fixation are not the main difficulties. Nevertheless we can imagine a reduction in the thigh pain due to the relative initial instability of the femoral component. We can conclude that the adjunction of a drug for this class of patient will be more original if the effect continues during many years to prevent the long term bone resorption. For older patient, with reduced bone quality, the common accepted solution for the femoral stem remains the cemented one. With the progression of the osteoporosis, we are confronted with very old patients suffering of osteoarthritis or femoral neck fracture. For this high morbid group of patients, the cemented phase of the surgical procedure remains dangerous [13]. For this patient population, the benefice of a uncemented femoral stem with fixation performance enhanced by the apposition of a specific drug could be easily demonstrated by a short term followup study [14]. 
DRUG DELIVERY SYSTEMS ALREADY IN CLINICAL USED FOR ORTHOPEDIC APPLICATIONS

As recently reviewed by $\mathrm{Wu}$ and Grainger [15], orthopedic implants used as drug delivery system have mainly targeted infection. Combination of bone cement and antibiotics can then be considered as a precursor approach in drug delivery system for orthopedic applications. Therapy of bone infections (osteomyelitis) was justified because of the poor accessibility of the infection site by common systemically administered antibiotics. This is mainly because bones are moderately perfused organs and because of a reduced blood supply associated with the formation of diffusional barriers in the infected bone tissues. Therefore, to improve the therapy, resorbable calcium phosphate ceramics $(\mathrm{CaP})$ materials [16], polymers such as methyl-methacrilate either as beads [17] or as cement [18] have been used as carriers for antibiotics. They release effective drug amounts at the site of infection for several months and the systemic drug concentration remains low. Among the various antibiotics, vancomycin $[19,20]$ and gentamycin have been extensively investigated and proved efficacy in human osteomyelitis [21].

\section{RESEARCH PERFORMED FOR ORTHOPEDIC IMPLANT USED AS DRUG DELIVERY SYSTEM}

Three approaches can be envisioned to deliver a drug with an orthopedic implant. The drug can be either coated on an implant surface, or incorporated in a biomaterials/cement scaffold or included in beads (Fig. 1). However and correspondingly to the clinical applications, most of the studies performed in drug delivery system for orthopedic applications were done for cements associated with antibiotics [22-26].

This approach has been extended to improve the properties of bone substitutes by associating an osteogenic factor with a synthetic material. In this attempt, growth factors, such as transforming growth factor [27], platelet-derived growth factor [28], bone morphogenetic proteins (BMP) [29], growth hormone [30] and insulin-like growth factor-1 [31] have been investigated successfully. In parallel, a major attempt in treating bone and soft tissue tumors is to maintain local long acting and effective high concen- trations of a chemotherapeutic drug at the site of tumors and, at the same time, producing minimum systemic side effects. Porous $\mathrm{CaP}$ ceramics have been demonstrated to be efficient as local drug delivery system for methotrexate or cis-platinum and successfully used in the treatment of mice osteosarcoma [32]. CaP ceramic could therefore have a major role in cancer chemotherapy in reducing the recurrence of tumors without the risk of systemic toxicity. Osteoarticular disorders associated with increased osteoclastic bone resorption (as observed in osteoporosis, Paget's disease, bone lytic tumors, periodontal disease, etc.) often lead to pathological fractures. They are widely treated by systemic administration of bisphosphonates, which are potent inhibitors of osteoclast activity. Association of $\mathrm{CaP}$ materials with bisphosphonates would increase the efficiency of bisphosphonate by being locally released and decreasing significant secondary effects (nephrotoxicity) observed after systemic treatments. In this objective, ceramic hydroxyapatite implants have been used in dental surgery. Denissen et al. [33] reported that bisphosphonates could be beneficial in preventing alveolar bone destruction associated with periodontal disease. He demonstrated the potential of bisphosphonate-complexed hydroxyapatite implants on the repair of alveolar bone.

The next step in orthopedic implant used as drug delivery system is then to combine the implant, the $\mathrm{CaP}$ and the bisphosphonate. Coating of orthopedic implants with $\mathrm{CaP}$ is routinely performed, and combination of $\mathrm{CaP}$ and bisphosphonate shows a good potential. In particular, combined with $\mathrm{CaP}$, bisphosphonate molecules can be released at very low concentrations [34], enabling evaluation of the biological activity of bisphosphonate-loaded materials using in vitro bone resorption assays. Bisphosphonate-loaded $\mathrm{CaP}$ materials were found to decrease the number and activity of osteoclastic cells [35]. Indeed, in a pit resorption assay, osteoclastic resorption activity was markedly reduced. In addition, bisphosphonate-loaded $\mathrm{CaP}$ exhibited a dose dependent inhibitory effect on osteoclastic activity similar to that observed with bisphosphonate solutions. These results clearly indicate that $\mathrm{CaP}$ matrices are suitable carriers for bisphosphonate, providing a bioactive drug delivery system whose release kinetics is compatible with the inhibition of bone resorption.

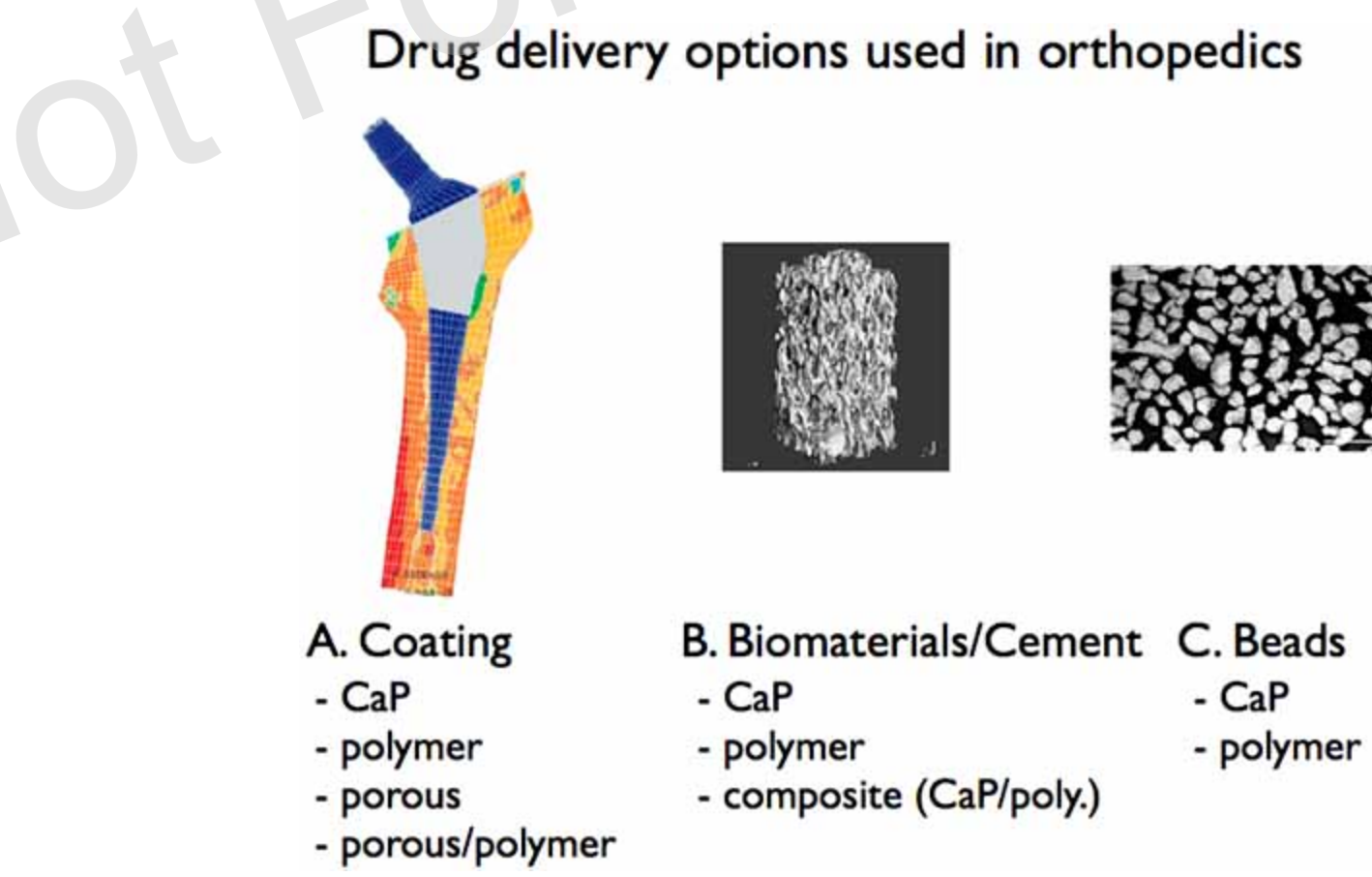

Fig. (1). Three different options can be proposed to locally deliver a drug with an orthopedic implant: A. The drug can be coated on an implant; B. The drug can be incorporated in a scaffold or cement; $\mathbf{C}$. The drug can be incorporated in beads. 
The effect of implant coated with $\mathrm{CaP}$ and Zoledronate -the latest bisphosphonate generation- has been evaluated in in vivo studies. Both on osteoporotic and normal rats, implants used as bisphosphonate delivery induced a denser peri-implant trabecular architecture compared to normal implant as well as a higher mechanical stability $[36,37]$. Similar results have been obtained with Zoledronate [38] or other bisphosphonates [39-41]. In Table 1, a summary of bisphosphonates used in a drug delivery system for orthopedic application is given. The combination of $\mathrm{CaP}$ and bisphosphonates does not change the surgical practice and needs only slight adjustments in the manufacturing process. Orthopedic implant coated with $\mathrm{CaP}$ and bisphosphonate could then be easily translated to routine clinical practices.

Bisphosphonate targets the catabolic aspect of bone remodeling. Beside bisphosphonates, different approaches have been proposed to control the catabolic bone remodeling, such as local delivery of anti-TNF therapy [42] or calcitonin [43]. An interesting review of possible therapeutical approach for controlling the bone catabolic process has been published [44].

In order to maintain bone quality around the implant, anabolic aspect of bone remodeling should also be considered. Indeed, one of the first studies for orthopedic implant used as drug delivery system was performed by adding transforming growth factor beta-1 to hydroxyapaptite coating [45]. A positive effect was observed on the amount of peri-implant bone ingrowths. The actual trend for anabolic process has focused on the use of BMP [46]. The BMP, usually rhBMP-2, can be delivered by combining it with a $\mathrm{CaP}$ coating of the implant. Either hip implants [47] or intramedullary nails [48] were tested to evaluate the local delivery of BMP. Bone ingrowths and accelerated bone healing have been observed. Interestingly, it has been proposed to combine the use of BMP with bisphosphonate in order to act both on catabolic and on anabolic aspects of bone remodeling [49].

There are two limitations for the use of rhBMP in clinical orthopedic practice, the first one is the cost and the second one is the supraphysiological dose needed to observe a therapeutical effect. A solution for these two problems may be to use not the BMP protein but its gene code. Indeed, this approach has been proposed by developing a DNA controlled-release coating for gene transfer [50]. In vivo gene transfection of the peri-implant cells to upregulate the production of BMP could then be obtained.

Beside CaP implant coating with $\mathrm{BMP}$ or bisphosphonate, different works have been performed combining metallic implant, polymer coating, and drugs such as TGB-beta1 or IGF-I [51]. Bone mechanical properties were increased when local delivery of these growth factors was used. An original approach has been proposed by coating the metallic implant with collagen and different proteins [52]. A controlled released of the proteins were obtained. Proteins or drugs can be effectively loaded on metallic implants by impregnated them with a polymer inside the pore of a titanium implant surface [53]. This approach may allow to better control the release of the drug. From a general point of view, it can be anticipated that most of the developed biomaterials are or will be combined with either growth factors or drugs in order to functionalize them more and not only to use them as filling materials for cavities [54-56]. It should be mentioned that one of the major problem in evaluating the effect of a pharmaceutical treatment to prevent peri-implant osteolysis is a reliable outcome measurement. Recently, a 3D-CT approach has been used and allowed to evaluate the volume of bone loss around implant [42].

\section{FUTURE FOR ORTHOPEDIC IMPLANTS}

While implants used as drug delivery system are well developed for cardiovascular applications (drug-eluting stents) and enter the market for diabete management (insulin pump), this approach is still at its infancy for orthopedic applications. Based on the growing evidences obtained in different in vivo studies, it seems quite clear that the orthopedic implant used as drug delivery system induces a faster bone healing as well as a more mechanically stable situation for the implant. Orthopedic implants are primarily designed to support mechanical load in the skeleton. As for the normal bone remodeling process, bone formation occurs where the skeleton is mechanically stimulated. It would then be beneficial to correlate the drug delivery with the mechanical situation surrounding the implant. This approach has been recently proposed by designing release of growth factors in response to mechanical signal [57]. The amount of drug concentration to be coated in order to obtain a controlled peri-implant bone remodeling could also be obtained using computer simulation [58, 59]. As mentioned in the introduction, orthopedic implant industries are entering a new field by considering more biologically oriented products. This new field has also some implications from the regulatory process. Indeed, orthopedic impland used as drug delivery system is considered as a combination product by the FDA (http://www.fda.gov/oc/combination/) and correspondingly the registration of these new implants followed a different process compared to traditional orthopedic implant. The combination product will be evaluated on its primary mode of ac-

Table 1. List of Works Associating Bisphosphonate and Calcium-Phosphate Carrier Used for Orthopedic Applications

\begin{tabular}{|c|c|c|c|c|}
\hline Targeted Application & Bisphosphonate & Carrier & Main Performance & Reference \\
\hline Alveolar bone destruction & $\begin{array}{l}\text { (3-dimethylamino-1- } \\
\text { hydroxypropylidene)-1,1-P-C-P }\end{array}$ & Hydroxyapatite & $\begin{array}{l}\text { In vitro: release affect osteo- } \\
\text { clasts but not osteoblast }\end{array}$ & Denissen, et al. [33] \\
\hline $\begin{array}{l}\text { Bone resorption around ortho- } \\
\text { pedic implant }\end{array}$ & Zoledronate & $\begin{array}{l}\text { Calcium deficient hydroxyapa- } \\
\text { tite }\end{array}$ & $\begin{array}{l}\text { In vitro: bisphosphonate release } \\
\text { can be controlled }\end{array}$ & Roussière, et al. [34] \\
\hline $\begin{array}{l}\text { Bone substitute in degenerative } \\
\text { bone disease }\end{array}$ & Zoledronate & $\begin{array}{c}\beta \text {-tricalcium phosphate, calcium } \\
\text { deficient hydroxyapatite, hy- } \\
\text { droxyapatite }\end{array}$ & $\begin{array}{l}\text { In vitro: inhibition of osteoclas- } \\
\text { tic activity }\end{array}$ & Josse, et al. [35] \\
\hline $\begin{array}{l}\text { Osteoporotic bone around } \\
\text { orthopedic implant }\end{array}$ & Zoledronate & Hydroxyapatite & $\begin{array}{l}\text { In vivo: increase of implant } \\
\text { mechanical stability }\end{array}$ & Peter, et al. [36] \\
\hline $\begin{array}{l}\text { Bone resorption around ortho- } \\
\text { pedic implant }\end{array}$ & Zoledronate & Hydroxyapatite & $\begin{array}{l}\text { In vivo: increase implant os- } \\
\text { teointegration }\end{array}$ & Peter, et al. [37] \\
\hline $\begin{array}{l}\text { Bone resorption around ortho- } \\
\text { pedic implant }\end{array}$ & Zoledronate & Hydroxyapatite & $\begin{array}{l}\text { In vivo: bone augmentation } \\
\text { around implant }\end{array}$ & Tanzer, et al. $[38]$ \\
\hline $\begin{array}{l}\text { Bone resorption around or- } \\
\text { thop/dental implant }\end{array}$ & Pamidronate & $\begin{array}{l}\text { Calcium-immobilized titanium } \\
\text { implant }\end{array}$ & $\begin{array}{l}\text { In vivo: new bone formation } \\
\text { around implant }\end{array}$ & Kajiwara, et al. [39] \\
\hline $\begin{array}{l}\text { Osteoporotic bone around } \\
\text { orthopedic implant }\end{array}$ & Ibandronate & Hydroxyapatite & $\begin{array}{l}\text { In vivo: increase osseointegra- } \\
\text { tion surface implant }\end{array}$ & Kurth, et al. [40] \\
\hline
\end{tabular}


tion and the regulation process will then depend on it. It would then be advantageous, from the regulations point of view, for an orthopedic implant used as drug delivery system to have its primary mode of action related to the implant part and not to its drug action. Apart from the delivery of antibiotic, there is actually no combination orthopedic product registered or on clinical trials (http://www. clinicaltrials. gov/ ct/action/GetStudy).

Combination orthopedic device represents certainly the future for orthopedic implant development and this is of importance not only for orthopedic companies, as combination of drugs and implants has been identified as the future of the pharma [60].

\section{REFERENCES}

[1] Haynes, D. R.; Crotti, T. N.; Zreiqat, H. Biomaterials, 2004, 25, 4877.

[2] Pioletti, D. P.; Kottelat, A. Biomaterials, 2004, 25, 5803.

[3] Suda, T.; Takahashi, N.; Udagawa, N.; Jimi, E.; Gillespie, M. T.; Martin, T. J. Endocr. Rev., 1999, 20, 345.

[4] Nehme, A.; Maalouf, G.; Tricoire, J. L.; Giordano, G.; Chiron, P.; Puget, J. Rev. Chir. Orthop. Reparatrice. Appar. Mot., 2003, 89, 593.

[5] Venesmaa, P. K.; Kroger, H. P.; Miettinen, H. J.; Jurvelin, J. S.; Suomalainen, O. T.; Alhav, E. M. J. Bone Miner. Res., 2001, 16, 2126.

[6] Yamaguchi, K.; Masuhara, K.; Yamasaki, S.; Nakai, T.; Fuji, T. Bone, 2003, 33, 144.

[7] Mjoberg, B. Acta Orthop. Scand., 1991, 62, 500.

[8] Venesmaa, P. K.; Kroger, H. P.; Miettinen, H. J.; Jurvelin, J. S.; Suomalainen, O. T.; Alhava, E. M. J. Bone Miner. Res., 2001, 16, 1056.

[9] Mjoberg, B. Orthopedics, 1997, 20, 1169.

[10] Liberman, U. A.; Weiss, S. R.; Broll, J.; Minne, H. W.; Quan, H.; Bell, N. H.; Rodriguez-Portales, J.; Downs, R. W., Jr.; Dequeker, J.; Favus, M. N. Engl. J. Med., 1995, 333, 1437.

[11] Graves, S. E.; Davidson, D.; Ingerson, L.; Ryan, P.; Griffith, E. C.; McDermott, B. F.; McElroy, H. J.; Pratt, N. L. Med. J. Aust., 2004, $180, \mathrm{~S} 31$.

[12] Soderman, P.; Malchau, H.; Herberts, P.; Zugner, R.; Regner, H.; Garellick, G. Acta Orthop. Scand., 2001, 72, 113.

[13] Gierer, P.; Landes, J.; Grubwinkler, M.; Gradl, G.; Lob, G.; Andress, H. J. Zentralbl. Chir., 2002, 127, 514.

[14] Andress, H. J.; von Ruckmann, B.; Zwonitzer, R.; Kahl, S.; Ringling, M.; Lob, G. Unfallchirurg, 2001, 104, 622.

[15] Wu, P.; Grainger, D. W. Biomaterials, 2006, 27, 2450.

[16] Radin, S.; Campbell, J. T.; Ducheyne, P.; Cuckler, J. M. Biomaterials, 1997, 18, 777

[17] Walenkamp, G. H.; Kleijn, L. L.; de Leeuw, M. Acta Orthop. Scand., 1998, 69, 518 .

[18] Stabile, D. E.; Jacobs, A. M. J. Am. Podiatr. Med. Assoc., 1990, 80, 345.

[19] Gautier, H.; Daculsi, G.; Merle, C. Biomaterials, 2001, 22, 2481

[20] Obadia, L.; Amador, G.; Daculsi, G.; Bouler, J. M. Biomaterials, 2003, 24, 1265.

[21] Yamashita, Y.; Uchida, A.; Yamakawa, T.; Shinto, Y.; Araki, N.; Kato, K. Int. Orthop., 1998, 22, 247.

[22] El-Ghannam, A.; Ahmed, K.; Omran, M. J. Biomed. Mater. Res. B. Appl. Biomater., 2005, 73, 277.

[23] Penner, M. J.; Masri, B. A.; Duncan, C. P. J. Arthroplasty, 1996, 11,939 .

[24] von Frauhofer, J. A.; Polk, H. C., Jr.; Seligson, D. J. Biomed. Mater. Res., 1985, 19, 751

[25] Walenkamp, G. H.; Vree, T. B.; van Rens, T. J. Clin. Orthop. Relat. Res., 1986, 205, 171.

[26] Yu, D.; Tsai, C. L.; Wong, J.; Fox, J. L. J. Formos. Med. Assoc., 1991, 90, 953.

[27] Blom, E. J.; Klein-Nulend, J.; Wolke, J. G.; van Waas, M. A.; Driessens, F. C.; Burger, E. H. J. Biomed. Mater. Res., 2002, 59, 265.

[28] Lee, Y. M.; Park, Y. J.; Lee, S. J.; Ku, Y.; Han, S. B.; Klokkevold, P. R.; Chung, C. P. J. Periodontol., 2000, 71, 418.
[29] Suh, D. Y.; Boden, S. D.; Louis-Ugbo, J.; Mayr, M.; Murakami, H.; Kim, H. S.; Minamide, A.; Hutton, W. C. Spine, 2002, 27, 353.

[30] Guicheux, J.; Gauthier, O.; Aguado, E.; Pilet, P.; Couillaud, S.; Jegou, D.; Daculsi, G.; Heymann, D. J. Bone. Miner. Res., 1998, 13,739.

[31] Laffargue, P.; Fialdes, P.; Frayssinet, P.; Rtaimate, M.; Hildebrand, H. F.; Marchandise, X. J. Biomed. Mater. Res., 2000, 49, 415

[32] Itokazu, M.; Sugiyama, T.; Ohno, T.; Wada, E.; Katagiri, Y. J. Biomed. Mater. Res., 1998, 39, 536.

[33] Denissen, H.; van Beek, E.; van den Bos, T.; de Blieck, J.; Klein, C.; van den Hooff, A. J. Bone. Miner. Res., 1997, 12, 290

[34] Roussiere, H.; Montavon, G.; Samia, L. B.; Janvier, P.; Alonso, B.; Fayon, F.; Petit, M.; Massiot, D.; Bouler, J. M.; Bujoli, B. J. Mater Chem., 2005, 15, 3869

[35] Josse, S.; Faucheux, C.; Soueidan, A.; Grimandi, G.; Massiot, D.; Alonso, B.; Janvier, P.; Laib, S.; Pilet, P.; Gauthier, O.; Daculsi, G.; Guicheux, J. J.; Bujoli, B.; Bouler, J. M. Biomaterials, 2005, 26, 2073.

[36] Peter, B.; Gauthier, O.; Laib, S.; Bujoli, B.; Guicheux, J.; Janvier, P.; van Lenthe, G. H.; Muller, R.; Zambelli, P. Y.; Bouler, J. M.; Pioletti, D. P. J. Biomed. Mater. Res. A., 2006, 76, 133.

[37] Peter, B.; Pioletti, D. P.; Laib, S.; Bujoli, B.; Pilet, P.; Janvier, P.; Guicheux, J.; Zambelli, P. Y.; Bouler, J. M.; Gauthier, O. Bone, $\mathbf{2 0 0 5}, 36,52$.

[38] Tanzer, M.; Karabasz, D.; Krygier, J. J.; Cohen, R.; Bobyn, J. D. Clin. Orthop. Relat. Res., 2005, 441, 30

[39] Kajiwara, H.; Yamaza, T.; Yoshinari, M.; Goto, T.; Iyama, S.; Atsuta, I.; Kido, M. A.; Tanaka, T. Biomaterials, 2005, 26, 581.

[40] Kurth, A. H.; Eberhardt, C.; Muller, S.; Steinacker, M.; Schwarz, M.; Bauss, F. Bone, 2005, 37, 204

[41] Tengvall, P.; Skoglund, B.; Askendal, A.; Aspenberg, P. Biomaterials, 2004, 25, 2133.

[42] Schwarz, E. M.; Campbell, D.; Totterman, S.; Boyd, A.; O'Keefe, R. J.; Looney, R. J. J. Orthop. Res., 2003, 21, 1049.

[43] Aldini, N. N.; Caliceti, P.; Lora, S.; Fini, M.; Giavaresi, G.; Rocca, M.; Torricelli, P.; Giardino, R.; Veronese, F. M. J. Orthop. Res., 2001, 19,955 .

[44] Rodan, G. A.; Martin, T. J. Science, 2000, 289, 1508

[45] Sumner, D. R.; Turner, T. M.; Purchio, A. F.; Gombotz, W. R.; Urban, R. M.; Galante, J. O. J. Bone Joint Surg. Am., 1995, 77, 1135

[46] Seeherman, H.; Wozney, J. M. Cytokine Growth Factor Rev., 2005, $16,329$.

[47] Bragdon, C. R.; Doherty, A. M.; Rubash, H. E.; Jasty, M.; Li, X. J.; Seeherman, H.; Harris, W. H. Clin. Orthop. Relat. Res., 2003, 417, 50.

[48] Schmidmaier, G.; Wildemann, B.; Cromme, F.; Kandziora, F.; Haas, N.; Raschke, M. In BMP-2 coating of implants increase biomechanical strength and accelerate bone remodeling in fracture treatment, 48th ORS, 2002, 0332.

[49] Seeherman, H.; Li, J.; Blake, C.; Gavin, D.; Wozney, J.; Bouxsein, M. L. In: Histology indicates bisphosphonate limit transient resorption without decreasing bone induction in nonhuman primate core defects treated with rhBMP-2/ACS, 23rd Annual Meeting of ASBMR, Phonix, 2001.

[50] Labhasetwar, V.; Bonadio, J.; Goldstein, S.; Chen, W.; Levy, R. J. J. Pharm. Sci., 1998, 87, 1347

[51] Wildemann, B.; Sander, A.; Schwabe, P.; Lucke, M.; Stockle, U.; Raschke, M.; Haas, N. P.; Schmidmaier, G. Biomaterials, 2005, 26 , 4035.

[52] Puleo, D. A. Artif. Cells Blood Substit. Immobil. Biotechnol., 1999 27, 65 .

[53] Agrawal, C. M.; Pennick, A.; Wang, X.; Schenck, R. C. J. Biomed. Mater. Res., 1997, 36, 516.

[54] Heller, J. Eur. Pharmacol. Contractor., 2003, 86

[55] Price, J. S.; Tencer, A. F.; Arm, D. M.; Bohach, G. A. J. Biomed Mater. Res., 1996, 30, 281.

[56] Saito, N.; Murakami, N.; Takahashi, J.; Horiuchi, H.; Ota, H.; Kato, H.; Okada, T.; Nozaki, K.; Takaoka, K. Adv. Drug. Deliv. Rev., 2005, 57, 1037 .

[57] Lee, K. Y.; Peters, M. C.; Anderson, K. W.; Mooney, D. J. Nature, 2000, $408,998$. 
[58] Peter, B.; Pioletti, D. P.; Terrier, A.; Rakotomanana, L. R. Comp.

[59] Zygourakis, K.; Markenscoff, P. A. Biomaterials, 1996, 17, 125. 